\title{
Using Tasks to Teach Communication Strategies
}

\section{Kio Iwai \\ Rikkyo University}

\section{Reference Data:}

Iwai, K (2020). Using tasks to teach communication strategies. In P. Clements, A. Krause, \& R. Gentry (Eds.), Teacher efficacy, learner agency. Tokyo: JALT.

https://doi.org/10.37546/JALTPCP2019-43

Active learning can be promoted by introducing activities that encourage negotiation of meaning among Japanese EFL learners. Negotiation of meaning is defined as interlocutors' endeavors to repair communication problems through the use of a variety of communication strategies such as comprehension checks, confirmation checks, and clarification requests. Empirical studies suggest that communication strategies are teachable at least to a certain degree. The author designed four kinds of information-gap activities and tested them in eight classes $(N=54)$. Although some forms of negotiation of meaning were observed in every class, especially after the teacher's feedback, students did not always use the strategies after the training. A questionnaire revealed that some students think negotiation of meaning is difficult. Others are afraid of annoying their interlocutors by negotiating meaning. Analyzing cultural and psychological barriers might offer a new avenue for developing students' ability to use communication strategies.

アクティブラーニングは、日本人EFL学習者に意味交渉を促す活動を紹介することにより推進することができる。意味交渉と は、対話者が伝達上の問題を修復しようとする努力を指し、理解度チエック、確認チエック、明確化要求などの様々な伝達方略 を介して行われる。実証的研究により、伝達方略は少なくともある程度までは教授可能であることが示されている。著者は 4 種類のインフォメーション・ギャップ活動を考案し、8クラス ( $N=54)$ において試行した。どのクラスにおいても、特に教師のフ

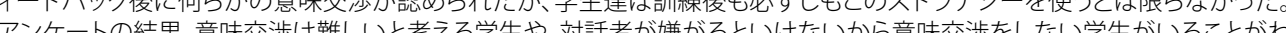
かった。文化的、心理的な障壁を分析することで、学生の伝達方略能力向上への新しい道が拓けるかもしれない。
T urturing communication skills and promoting active learning are priorities for

the Japanese Ministry of Education, Culture, Sports, Science, and Technology (MEXT). Active learning is defined by the Central Council for Education (2016) as proactive, interactive, and deep learning. These terms appear in MEXT's websites (MEXT, 2019), and can often be heard as buzzwords at Japanese universities. When it comes to classroom practices, however, there is relatively little consensus among instructors as to how best to achieve these goals. This gap between the ideal and reality can come sharply into focus when getting students to use English for communication in the classroomparticularly, getting Japanese students to talk to each other in English during class. Some studies have reported levels of silence, anxiety, and reticence among Japanese EFL learners that are difficult to overcome (Cutrone, 2009; Harumi, 2011; King, 2013).

The students' aversion to engaging in conversation can be attributed to an over focus on grammatical accuracy and translation in pre-tertiary EFL classrooms, which in turn comes from a heavy emphasis on preparation to pass difficult examinations at the secondary school level (Cook, 2009; Underwood, 2012). Understandably, students may be afraid to experiment even with the language that they do have, let alone with new things they are learning, in order to communicate. As such, they tend to be obsessed with speaking with correct grammar and feel responsible when they fail to make themselves understood. Teachers, on the other hand, often do not teach what to do when there is a communication breakdown. As a result, students lack practice in the act of negotiating meaning (Foster, 1998), of checking and clarifying what they say to each other, in order to achieve mutual understanding.

Fundamental to communicative language teaching (CLT) is the theory of communicative competence, set forth prominently by Hymes (1972). One component of the communicative competence model proposed by Canale and Swain (1980) is strategic competence. As Dörnyei and Thurrell (1991, p.16) observed, "The lack of fluency or conversational skills that students often complain about is, to a considerable extent, due to the underdevelopment of strategic competence." They pointed out Tarone and 
Yule's (1989) observation that "there are few, if any, materials available at present that teach learners how to use communication strategies when problems are encountered in the process of transmitting information" (pp. 114-115), and argued for the inclusion of explicit training in communication strategies (CSs) as part of EFL classroom routines.

The underdevelopment of strategic competence is especially true in Japan, where most pre-university classroom time is spent developing grammatical competence, another component of Canale \& Swain's (1980) model. A great deal of research has been devoted to CLT, including in the particular context of Japan (see e.g., Butler, 2011; Kavanagh, 2012; Sakui, 2004), and considerable literature on CSs points out the benefits of strategy training in classrooms (see e.g., Faucette, 2001; Lam, 2006; Naughton; 2006; Willems, 1987). There is, however, very little literature like Dörnyei and Thurrell's (1991) that offers detailed activity ideas for CS training, particularly ones suited for lower level learners in Japanese universities. This paper is an attempt to fill this gap by detailing activities that promote the use of CSs and negotiation of meaning in Japanese university EFL classes that focus on student-student discussion.

English Discussion Class (EDC) is a compulsory 28-week course using a communicative approach for all 1st-year students at a private university located in Tokyo, Japan. Although students learn phrases for negotiation of meaning called communication skills (see Figure 1) at the beginning of the course and are encouraged to use them in every lesson, they often do not try to understand their peers even when there is an apparent communication breakdown.

\begin{tabular}{|c|c|}
\hline \multicolumn{2}{|c|}{ Comprehension } \\
\hline Active listening & Check understanding \\
\hline I see. Okay. Right. Sure. Uh-huh. Really? & Do you understand? \\
\hline Sorry, I don't understand. & Do you follow me? \\
\hline Sorry, I don't follow you. & Do you see what I mean? \\
\hline \multicolumn{2}{|c|}{ Paraphrasing } \\
\hline Paraphrasing others & Paraphrasing yourself \\
\hline Do you mean...? & I mean... \\
\hline So, are you saying...? & What I'm saying is ... \\
\hline So, in other words, ...? & In other words, ... \\
\hline
\end{tabular}

\begin{tabular}{ll}
\hline \multicolumn{2}{c}{ Clarification } \\
\hline \multicolumn{1}{c}{ Asking for explanation } & \multicolumn{1}{c}{ Asking for repetition } \\
\hline Can you explain ...? & Could you repeat that, please? \\
What does $\{\mathrm{X}\}$ mean? & Could you say that again, please? \\
\hline
\end{tabular}

Figure 1. EDC communication skills. Reprinted with permission from Brereton, Lesley, Schaefer, \& Young, 2018

In order to respond to this problem, the following hands-on activities were designed. They were equipped with mechanisms that prompt students to negotiate for meaning when they have communication problems. Because these activities do not require special preparation or training other than activity cards and need less than 10 minutes to implement, they can contribute to improving teacher efficacy especially for less experienced teachers. Moreover, these activities heighten learner agency by helping learners engage in communication more proactively.

\section{Negotiation Strategies}

Negotiation of meaning is defined as interlocutors' endeavor to repair communication problems "by engaging in interactional work to secure mutual understanding" (Ellis 2015, p. 322). Negotiation of meaning is carried out by using a variety of CSs. Long (1983) classified these strategies into three categories: comprehension checks, confirmation checks, and clarification requests. Comprehension checks are used when speakers attempt to ensure if other people have understood what has just been said. Confirmation checks help confirm listeners' own understanding of what other people have said. Clarification requests are made when listeners need more information to understand what others have said. As well as comprehension checks, confirmation checks, and clarification requests, Ellis (2008) includes recast, repetition, metalinguistic feedback, elicitation, and explicit correction as negotiation strategies. Table 1 is the list of negotiation strategies suggested by Long (1983) and Ellis (2008) contrasted with EDC Communication Skills. 
Iwai: Using Tasks to Teach Communication Strategies

Table 1. Long's and Ellis's Negotiation Strategies Compared With EDC Communication Skills

\begin{tabular}{|c|c|c|}
\hline $\begin{array}{l}\text { Long's and Ellis's } \\
\text { negotiation strategies }\end{array}$ & $\begin{array}{l}\text { Equivalent } \\
\text { communication skills } \\
\text { taught in EDC }\end{array}$ & Examples \\
\hline Comprehension check & Comprehension & "Do you follow me?" \\
\hline Confirmation check & Paraphrasing & “Do you mean X?" \\
\hline Clarification requests & Clarification & "Can you explain?" \\
\hline Recast & Paraphrasing & $\begin{array}{l}\text { A: "Effectly." } \\
\text { B: "Effectively?" }\end{array}$ \\
\hline Repetition & NA & $\begin{array}{l}\text { A :"Effectly." } \\
\text { B: "Effectly?" }\end{array}$ \\
\hline Metalinguistic feedback & NA & $\begin{array}{l}\text { A: "How do you say 'hoikuen' in } \\
\text { English?" } \\
\text { B: "Nursery." }\end{array}$ \\
\hline Elicitation & NA & $\begin{array}{l}\text { A: "More 'hoikuen' is ..." } \\
\text { B: "More nurseries are ...?" }\end{array}$ \\
\hline Explicit correction & NA & $\begin{array}{l}\text { A: "More 'hoikuen' is necessary." } \\
\text { B: "Oh, more nurseries are } \\
\text { necessary." }\end{array}$ \\
\hline
\end{tabular}

Note. Negotiation strategies are taken from Long (1983) and Ellis (2008). EDC = English Discussion Class.

By employing negotiation strategies, second language learners are expected to adjust their speech and are also able to receive more comprehensible input. According to Long's $(1983,1996)$ interaction hypothesis, learners acquire a second language best by receiving interactionally modified input; that is, when negotiation of meaning occurs.

\section{Teachability of Negotiation of Meaning}

There are two competing claims for and against the teachability of CSs. Dissenting views include Bialystok's (1990) "What one must teach students of a language is not strategy, but language" (p. 147) and Kellerman's (1991) “Teach the learners more language and let the strategies look after themselves" (p. 158). These claims, however, are not supported by empirical research as Yule and Tarone (1997) pointed out. On the other hand, there are several empirical studies that argued for the effectiveness of teaching CSs. Following are three such studies that focused on the teachability of negotiation of meaning among others.

Dörnyei (1995) argued that teaching CSs is not just about passing on information. He reported a study that investigated the effects of teaching three kinds of CSs including circumlocution (paraphrase) to high school students in Hungary. The training included awareness-raising discussions, explicit strategy teaching, and practice activities. For example, students compared and discussed various dictionary definitions for a word (awareness raising). Then, they were asked to describe objects and later more abstract notions (practice activities). The posttraining results showed a significant improvement in both quality and quantity of strategy use by the treatment group.

Nakatani (2005) examined how Japanese college students changed their use of CSs after receiving explicit oral communication strategy instructions including negotiation of meaning and reflecting on their strategy use in every lesson. The results showed that the students significantly increased their use of negotiation strategies compared to a control group and significantly improved their proficiency in oral communication tests. He also found that the students who received training made longer utterances and modified their speech to achieve comprehension.

Rabab'ah (2016) provided communication strategy training to university students in Jordan. The training included explicitly teaching oral CSs and certain phrases, matching words and their definitions, guessing words, and role play. The posttests showed that the experimental group significantly outperformed the control group in the use of circumlocution (paraphrase), appeal for help, asking for repetition, and self-repair. However, no significant differences were found between the two groups in the use of clarification requests, confirmation requests, and guessing strategies. Another finding was that the training enabled students to try out their hypotheses about language as well as solve communication problems.

The above studies suggest that CSs are teachable at least to a certain degree. In view of these empirically supported insights, the present study suggests the use of various tasks to teach negotiation of meaning. 


\section{Using Tasks}

Tasks are defined as activities that require "learners to use language, with emphasis on meaning, to attain an objective" (Bygate, Skehan, \& Swain, 2001). There have been a number of studies conducted to investigate the negotiation of meaning that occurred during tasks. Although there are a variety of tasks, it has been found that some kinds of tasks encourage more negotiation of meaning than others. For example, pair work and group work promote more negotiation of meaning than teacher-fronted instruction (Doughty \& Pica 1986; Johnson, 1995; Long \& Porter, 1985; Pica \& Doughty 1985). Two-way tasks, which require information exchange in both directions, induce more negotiation of meaning than one-way tasks with mono-directional information flow (Pica, Young, \& Doughty, 1987). Likewise, closed tasks, which require learners to reach a single and correct solution or a limited set of solutions, provide more opportunities for negotiation of meaning than open tasks with no determined solution (Loschky \& BleyVroman, 1993; Pica, Holiday, Lewis, \& Morgenthaler, 1989; Plough \& Gass, 1993).

\section{Activities}

In order to promote negotiation of meaning among students, I designed four kinds of task activities and tested them in eight English discussion classes in the last lesson of the year as a review of EDC Communication Skills (negotiation of meaning). The participants were 54 first-year university students ( 29 male and 25 female) enrolled in a private university in Tokyo, Japan. Their English proficiency ranged from 180 to 655 on TOEIC. All the participants gave informed consent, and the project was cleared with the university's institutional review board. Teacher's notes were kept in every class to record students' use of negotiation of meaning and other observations.

The activities used in this study are information-gap tasks. An information-gap task is characterized by several features: Only one outcome or answer is considered possible, appropriate, or correct and reaching it requires a verbal exchange of information among task participants (Ellis, 2003; Pica, Kanagy, \& Falodun cited in Pica, 2005). As all activities use only picture cards without words, they are adaptable to learners of any age group and of any English level. The level of English needed to describe the pictures, however, needs to be controlled so that it is slightly above the learners' actual English levels. This is because the purpose of these activities is to encourage negotiation of meaning. If learners can describe everything easily and understand everything their partners say without trouble, negotiation of meaning can hardly be expected to occur. For example, the English level needed to describe the pictures in Appendix A is a little over that of university students with TOEIC scores of 300-500, but they are too easy for university students with TOEIC scores over 600. It is also important that the original pictures are recognizable to the learners when they see them at the end of the activity. For example, university students who have lived in European countries would easily understand the picture in Appendix C, but young students who have been brought up in Japan probably would not understand what they are doing. Each activity needs about 10 minutes for instruction, implementation, and teacher feedback. It is also possible to use two different sets of cards or two different activities in the test-teach-test teaching method, with a feedback session in the middle. Test-teach-test is a teaching method where "learners first complete a task or activity without help from the teacher. Then, based on the problems seen, the teacher plans and presents the target language. Then the learners do another task to practice the new language" [British Council, n.d.]. In such cases, it should take about 15 minutes for the whole process.

\section{Activity 1: Spot the Difference}

In this activity, students try to identify the differences between two pictures while looking at only one picture.

\section{Preparation}

Prepare a set of picture cards (Cards A and B: refer to Appendix A) for each pair of students. The two pictures should look similar to each other, but not be exactly the same. Suitable pictures may be found online and in commercially available activity books. Alternatively, teachers can create their own picture cards. One way of making them is to draw any picture on a piece of paper, make a photocopy, and add or erase some parts of the original drawing. Another idea is to arrange many things on a table, take a picture of it, rearrange them, and take a picture again.

\section{Procedure}

Step 1: Put students into pairs

Step 2: Give instructions to the students.

- Students in the same pair will get similar but different pictures.

- Each pair should find as many differences as possible between the pictures.

- Students should not show their pictures to each other.

- Students can only use English. 
- Students should not use gestures.

- Students have 5 minutes for the activity.

Step 3: Give a different card to each student in each pair.

Step 4: After 5 minutes, stop the activity and ask how many differences they have found. Step 5: Allow students to quickly compare the pictures by showing them to each other.

Step 6: Give feedback on the use of negotiation of meaning and any other language items as needed.

\section{Activity 2: Jigsaw Storytelling}

In this activity, students have different parts of a four-frame comic strip. They alternately explain the pictures, trying to tell a story together.

\section{Preparation}

Prepare a set of picture cards by cutting a four-frame comic strip into two (Cards A and B: refer to Appendix B). When choosing a story, the more difficult for students to guess the whole story, the more negotiation of meaning should occur. According to Robinson (2001), more cognitively complex interactive tasks are likely to prompt comprehension difficulty, thus leading to greater amounts of negotiation of meaning. Suitable pictures may be found online and in commercially available comic books. Make sure to choose picture-only comic strips because when there are words, students tend to depend on them and do not try to describe the situation using their own resources. Although students generally enjoy working on comic strips with a twist ending, any sequence of pictures can be used. For example, it is possible to use parts of furniture assembly instructions without showing the final product and have students guess what it will become.

\section{Procedure}

Step 1: Put students into pairs.

Step 2: Give instructions to the students.

- Students in the same pair will get different parts of the same picture story.

- Students explain the picture to each other to find out what the whole story is.

- Students should not show their pictures to each other.
- Students can only use English.

- Students should not use gestures.

- Students have 5 minutes for the activity.

Step 3: Give a different card to each student in each pair.

Step 4: After 5 minutes, stop the activity and ask the students what they think the story is. Step 5: Allow students to quickly show the pictures to each other.

Step 6: Give feedback on the use of negotiation of meaning and any other language items as needed.

\section{Activity 3: Half-Picture Info Gap}

In this activity, each student gets only half of the original picture. They explain their picture to each other trying to figure out together what the original picture was.

\section{Preparation}

Prepare a set of picture cards by cutting a picture into two (Cards A and B: refer to Appendix C). The picture can be cut in half horizontally or vertically or any other way. Just make sure to cut it so that it is difficult for both students to guess what the whole picture is. Please note, however, it is more difficult to find suitable pictures for this activity than other activities because the picture should not make sense when cut in half, and it should make sense when put together. Certain kinds of nonsense illustrations, surrealist paintings, and pictures of unique inventions can be used for this activity. Alternatively, a picture may be cut out into a very complicated shape (for example, a twelve-rayed star shape) so that the whole picture cannot be easily guessed.

\section{Procedure}

Step 1: Put students into pairs.

Step 2: Give instructions to the students.

- Students in the same pair will get half of the same picture.

- Students explain the picture to each other to find out what the whole picture is.

- Students should not show their pictures to each other.

- Students can only use English.

- Students should not use gestures. 
- Students have 5 minutes for the activity.

Step 3: Give a different card to each student in each pair.

Step 4: After 5 minutes, stop the activity and ask the students what they think the picture is.

Step 5: Allow students to quickly show the pictures to each other.

Step 6: Give feedback on the use of negotiation of meaning and any other language items as needed.

\section{Activity 4: Back-to-Back Drawing}

In this activity, students sit back-to-back. One of them describes a picture while the other one tries to draw it.

\section{Preparation}

Prepare a picture card (refer to Appendix D) and a piece of paper. The picture should not be too simple so that students need to make an effort to describe it. For example, pictures of several objects in complicated positional relationships and pictures of objects in unusual shapes are suitable for this activity. Line drawings in black and white are more suitable than photographs.

\section{Procedure}

Step 1: Put students into pairs.

Step 2: Give instructions to the students.

- In each pair, one student gets a picture card and another one gets a piece of paper.

- Students sit back-to-back.

- The student with a picture card describes the picture. The student with a piece of paper draws a picture according to their partner's description.

- Students should not show their pictures to each other.

- Students can only use English.

- Students have 5 minutes for the activity.

Step 3: Give a picture card to one student and a piece of paper to the other student in each pair.

Step 4: After 5 minutes, stop the activity and ask the students to show their pictures to each other.
Step 5: Give feedback on the use of negotiation of meaning and any other language items as needed.

\section{Discussion}

\section{Students' Use of Negotiation of Meaning}

Overall, students seemed to be actively engaged in the activities. Picture-only activity cards were easily accepted by the students who usually seemed reluctant to read English. Some forms of negotiation of meaning were observed in every class. For example, repetition and confirmation checks (paraphrasing others) were observed in all eight classes, and comprehension checks were spotted in four classes. In the four classes where two activities with teacher feedback in between (test-teach-test teaching approach) were used, more instances of negotiation of meaning were recorded in the teacher's notes in the second activity than in the first activity. This may be because the feedback raised awareness of negotiation strategies among students. My feedback included an example of students' interaction, how negotiation of meaning helped them out of communication breakdown, and what other expressions can be used in more formal occasions (see Figure 2).

\section{A: What shape? B: Shape? Simple. $A$ : (Do you mean) not circle?}

Figure 2. An example of feedback.

Reasons Why Students Do Not Use Negotiation of Meaning Although many students used some kind of negotiation strategies during the information-gap activities, the next challenge is how to get students to internalize the 
strategies and get them to actually use them when they communicate in other classroom activities, for example, peer-peer discussions. Despite the fact that these students had learned negotiation of meaning phrases (communication skills) at the beginning of the semester, many of them did not always use them even when they experienced communication breakdowns. If that is the case, knowing the reasons why they do not sometimes use strategies might help design a whole course of communication strategy training. With this in mind, I administered a short questionnaire to students in eight classes in the last lesson of the semester (see Appendix E for the questionnaire). A total of 53 students responded to the questionnaire, which asked how often students use communication skills and why they do not always use the skills for five kinds of negotiation strategies: checking understanding (comprehension check as a speaker), saying that you do not understand (comprehension as a listener), paraphrasing others (confirmation as a listener), paraphrasing yourself (confirmation as a speaker), and clarification (as a listener)

The results of the questionnaire showed that the majority of the students (79\%) said they always or often use comprehension checks as a speaker. For the other strategies (comprehension checks as a listener, paraphrasing others, paraphrasing yourself, and clarification), however, the number of students who sometimes use and rarely use the strategies exceeded the number of students who always or often use them. The major reason for not using paraphrasing others, paraphrasing yourself, and clarification was "It is difficult to use the skill." This indicates strategy training may be effective to acquire these kinds of skills. What is worth noting is that some students answered that they do not use some strategies because they are afraid others would be annoyed if they used them. For example, 25\% gave this reason for not saying, "Sorry, I don't understand." Further, $23 \%$ cited this reason for not using clarification requests. There could be cultural and psychological reasons behind these responses that are worth further examination.

\section{Conclusion}

The hands-on activities for EFL teachers to readily teach CSs and to promote negotiation of meaning outlined in this paper are a tentative realization of MEXT's vision for active learning in classrooms. These activities allow for raising awareness, encouraging students to be willing to take risks, teaching CSs directly, and providing opportunities for practicing strategies. By using these activities, it is possible to increase the students' use of CSs at least temporarily. The next challenge is how to have students continue to use CSs effectively in communication elsewhere. The survey revealed that the major reason for students not using paraphrasing and clarification was that they thought these skills were difficult. There is scope for designing other types of CS training. Another finding was that a certain number of students did not use some strategies because they were afraid others might be annoyed if they used them. Given this, future directions could include analyzing the cultural and psychological barriers that might prevent students from using the CSs, changing the task complexity according to students' ability and interests, and developing a syllabus that is focused on expanding and practicing students' repertoire of CSs.

\section{Bio Data}

Kio Iwai is an adjunct lecturer at Rikkyo University's Center for Foreign Language Education and Research. She holds an MA in TESOL from the Institute of Education, University of London. Her current interests include learner beliefs, communication strategies, and English remedial education. She can be reached at <kio-iwai@rikkyo. ac.jp>

An earlier version of this article appeared in 2019 as "Designing tasks to encourage negotiation of meaning" in New Directions in Teaching and Learning English Discussion, 7, 126-132. https://doi.org/10.14992/00017546

\section{References}

Bialystok, E. (1990). Communication strategies: A psychological analysis of second-language use. Oxford, England: Basil Blackwell.

Brereton, P., Lesley, J., Schaefer, M. Y., \& Young, D. (2018). What do you think?: Interactive skills for effective discussion 2, Book III. (9th ed.). Tokyo: DTP Publishing.

British Council. (n.d.). Test teach test. Teaching English. Retrieved from https://www. teachingenglish.org.uk/article/test-teach-test

Butler, Y. G. (2011). The implementation of communicative and task-based language teaching in the Asia-Pacific region. Annual Review of Applied Linguistics, 31, 36-57. https://doi.org/10.1017/ s0267190511000122

Bygate, M., Skehan, P., \& Swain, M. (2001). (Eds.). Researching pedagogic tasks, second language learning, teaching, and testing. Harlow, England: Longman.

Canale, M., \& Swain, M. (1980). Theoretical bases of communicative approaches to second language teaching and testing. Applied Linguistics, 1(1), 1-47. https://doi.org/10.1093/applin/1.1.1 
Central Council for Education. (2016). 幼稚園、小学校、中学校、高等学校及び特別支援学校の学習 指導要領等の改善及び必要な方策等について [On the improvement of educational guidelines for kindergartens, elementary schools, junior high schools, high schools and special-needs schools and necessary measures (proposal)]. Retrieved from https://www.mext.go.jp/b_menu/shingi/ chukyo/chukyo0/toushin/_icsFiles/afieldfile/2017/01/10/1380902_0.pdf

Cook, M. (2009). Factors inhibiting and facilitating Japanese teachers of English in adopting communicative language teaching methodologies. $k @ t a, 11(2), 99-116$. https://doi.org/10.9744/ kata.11.2.99-116

Cutrone, P. (2009). Overcoming Japanese EFL learners' fear of speaking. Language Studies Working Papers, 1, 55-63. Retrieved from https://pdfs.semanticscholar.org/802e/c28e5b0ab4082b2f6f711 38c5af698a1bfe2.pdf

Doughty, C. \& Pica, T. (1986). "Information gap" tasks: Do they facilitate second language acquisition? TESOL Quarterly, 20, 305-325. https://doi.org/10.2307/3586546

Dörnyei, Z. (1995). On the teachability of communication strategies. TESOL Quarterly, 29(1), 55-85. https://doi.org/10.2307/3587805

Dörnyei, Z., \& Thurrell, S. (1991). Strategic competence and how to teach it. ELT Journal, 45(1), 16 23. https://doi.org/10.1093/elt/45.1.16

Ellis, R. (2003). Task-based language learning and teaching. Oxford, England: Oxford University Press.

Ellis, R. (2008). The study of second language acquisition (2nd ed.). Oxford, England: Oxford University Press.

Ellis, R. (2015). Understanding second language acquisition (2nd ed.). Oxford, England: Oxford University Press.

Faucette, P. (2001). A pedagogical perspective on communication strategies: Benefits of training and an analysis of English language teaching materials. University of Hawai’i Second Language Studies, 19(2), 1-40.

Foster, P. (1998). A classroom perspective on the negotiation of meaning. Applied Linguistics, 19(1), 1-23. https://doi.org/10.1093/applin/19.1.1

Harumi, S. (2011). Classroom silence: Voices from Japanese EFL learners. ELT Journal, 65(3), 260269. https://doi.org/10.1093/elt/ccq046

Hymes, D. (1972). On communicative competence. In J. B. Pride \& J. Holmes (Eds.), Sociolinguistics: Selected readings (pp. 269-293). Harmondsworth, England: Penguin.

Iwai. K. (2019). Designing tasks to encourage negotiation of meaning. New directions in teaching and learning English discussion, 7, 126-132. https://doi.org/10.14992/00017546

Johnson, K. (1995). Understanding communication in second language classrooms. New York, NY: Cambridge University Press.
Kavanagh, B. (2012). The theory and practice of communicative language teaching in Japan Academic Research International, 2(2), 730. Retrieved from http://www.savap.org.pk/journals/ ARInt./Vol.2(2)/2012(2.2-80).pdf

Kellerman, E. (1991). Compensatory strategies in second language research: A critique, a revision, and some (non-) implications for the classroom. In R. Phillipson, et al., (Eds.) Foreign/second language pedagogy research: A commemorative volume for Claus Faerch (pp. 142-161). Clevedon, England: Multilingual Matters.

King, J. (2013). Silence in the second language classrooms of Japanese universities. Applied Linguistics, 34(3), 325-343. https://doi.org/10.1093/applin/ams043

Lam, Y. K. W. (2006). Gauging the effects of ESL oral communication strategy teaching: A multimethod approach. Electronic Journal of Foreign Language Teaching, 3(2), 142-157. Retrieved from https://e-flt.nus.edu.sg/v3n22006/lam.pdf

Long, M. (1983). Native speaker/non-native speaker conversation and the negotiation of comprehensible input. Applied linguistics, 4(2), 126-141. https://doi.org/10.1093/applin/4.2.126

Long, M. (1996). The role of the linguistic environment in second language acquisition. In W. Ritchie \& T. Bhatia (Eds.). Handbook of second language acquisition (pp. 413-468). New York, NY: Academic Press.

Long, M., \& Porter, P. (1985). Group work, interlanguage talk and second language acquisition. TESOL Quarterly, 19(2), 207-228. https://doi.org/10.2307/3586827

Loschky, L., \& Bley-Vroman, R. (1993). Grammar and task-based methodology. In G. Crookes \& S. Gass (Eds.). Tasks and language learning: integrating theory and practice (pp. 123-167). Clevedon, England: Multilingual Matters.

MEXT. (2019). Overview of the Ministry of Education, Culture, Sports, Science and Technology. Retrieved December 22, 2019, from https://www.mext.go.jp/en/about/pablication/__icsFiles/afie ldfile/2019/03/13/1374478_001.pdf

Nakatani, Y. (2005). The effects of awareness raising training on oral communication strategy use. The Modern Language Journal, 89(1), 76-91. https://doi.org/10.1111/j.0026-7902.2005.00266.x

Naughton, D. (2006). Cooperative strategy training and oral interaction: Enhancing small group communication in the language classroom. The Modern Language Journal, 90(2), 169-184. https:// doi.org/10.1111/j.1540-4781.2006.00391.x

Pica, T. (2005). Classroom learning, teaching, and research: Task-based perspective. The Modern Language Journal, 89(3), 339-352. https://doi.org/10.1111/j.1540-4781.2005.00309.x

Pica, T., \& Doughty, C. (1985). Input and interaction in the communicative language classroom: A comparison of teacher-fronted and group activities. In S. M. Gass \& C. G. Madden (Eds.). Input and second language acquisition (pp. 115-132). Rowley, MA: Newbury House.

Pica, T., Young, R., \& Doughty, C. (1987). The impact of interaction on comprehension. TESOL Quarterly, 21(4), 737-758. https://doi.org/10.2307/3586992 
Pica, T., Holiday, L., Lewis, N., \& Morgenthaler, L. (1989). Comprehensible output as an outcome of linguistics demands on the learner. Studies in second language acquisition, 11(1), 63-90. https:// doi.org/10.1017/s027226310000783x

Plough, I., \& Gass, S. (1993). Interlocutor and ask familiarity: Effects on interactional structure. In G. Crookes \& S. Gass (Eds.). Tasks and language learning: Integrating theory and practice (pp. 3556). Clevedon, England: Multilingual Matters.

Rabab'ah, G. (2016). The effect of communication strategy training on the development of EFL learners' strategic competence and oral communicative ability. Journal of psycholinguistic research, 45(3), 625-651. https://doi.org/10.1007/s10936-015-9365-3

Robinson, P. (2001). Task complexity, cognitive resources, and syllabus design: A triadic framework for investigating task influences on SLA. In P. Robinson (Ed.), Cognition and second language instruction (pp. 287-318). New York, NY: Cambridge University Press.

Sakui, K. (2004). Wearing two pairs of shoes: Language teaching in Japan. ELT Journal, 58(2), 155163. https://doi.org/10.1093/elt/58.2.155

Tarone, E., \& Yule, G. (1989). Focus on the language learner. Oxford, England: Oxford University Press.

Underwood, P. (2012). Teacher beliefs and intentions regarding the instruction of English grammar under national curriculum reforms: A theory of planned behavior perspective. Teaching and Teacher Education, 28(6), 911-925. https://doi.org/10.1016/j.tate.2012.04.004

Willems, G. M. (1987). Communication strategies and their significance in foreign language teaching. System, 15(3), 351-364. https://doi.org/10.1016/0346-251x(87)90009-1

Yule, G., \& Tarone, E. (1997). Investigating communication strategies in L2 reference: pros and cons. In G. Kasper \& E. Kellerman (Eds.). Communication strategies: Psycholinguistic and sociolinguistic perspectives (pp. 17-30). London, England: Longman.

\section{Appendix A}

Example of Picture Cards for Spot the Difference

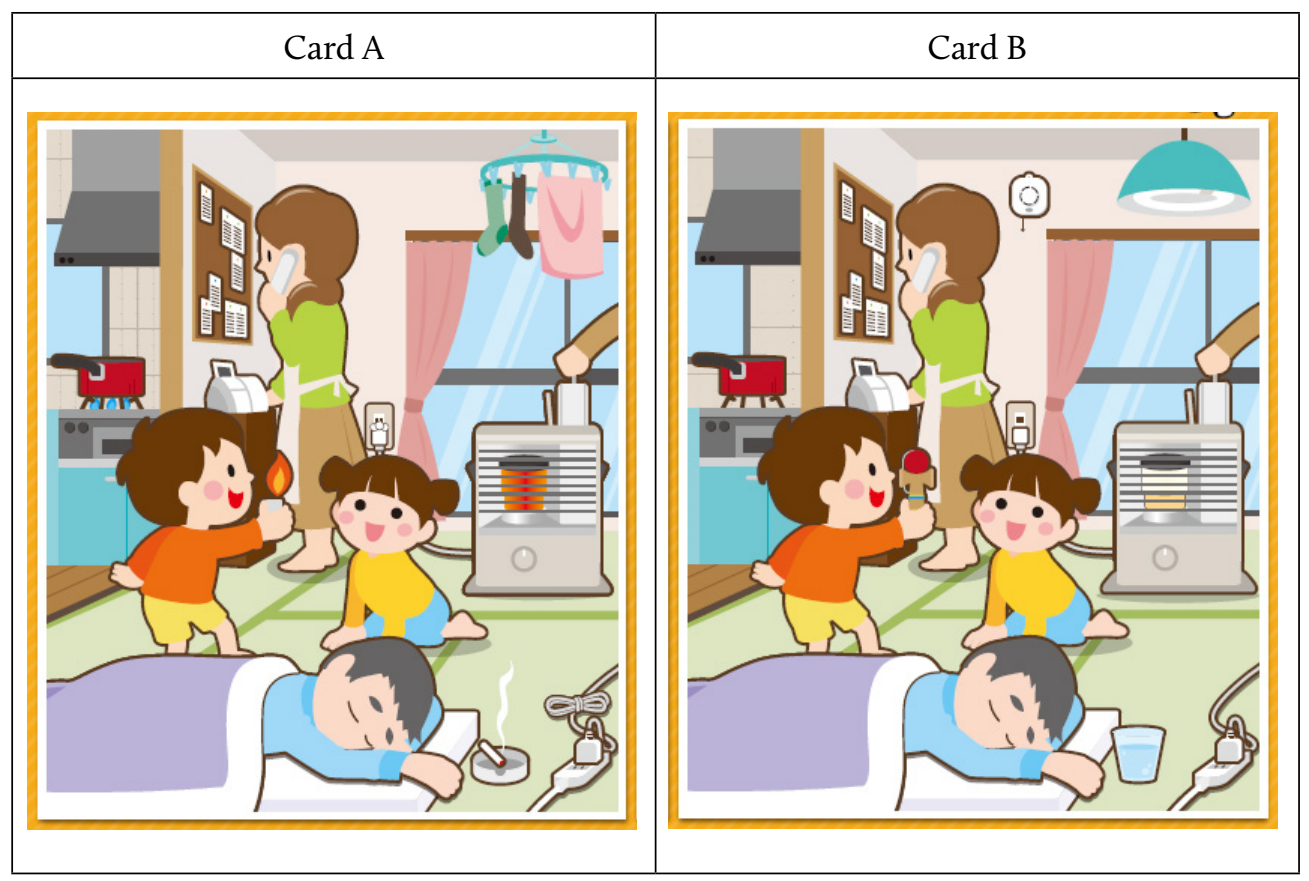

Note: Reprinted with permission from Niigata Prefecture. The original images can be found at https://www.pref.niigata.lg.jp/sec/shobo/1356854863978.html 
Iwai: Using Tasks to Teach Communication Strategies

Appendix B

Example of Picture Cards for Jigsaw Storytelling

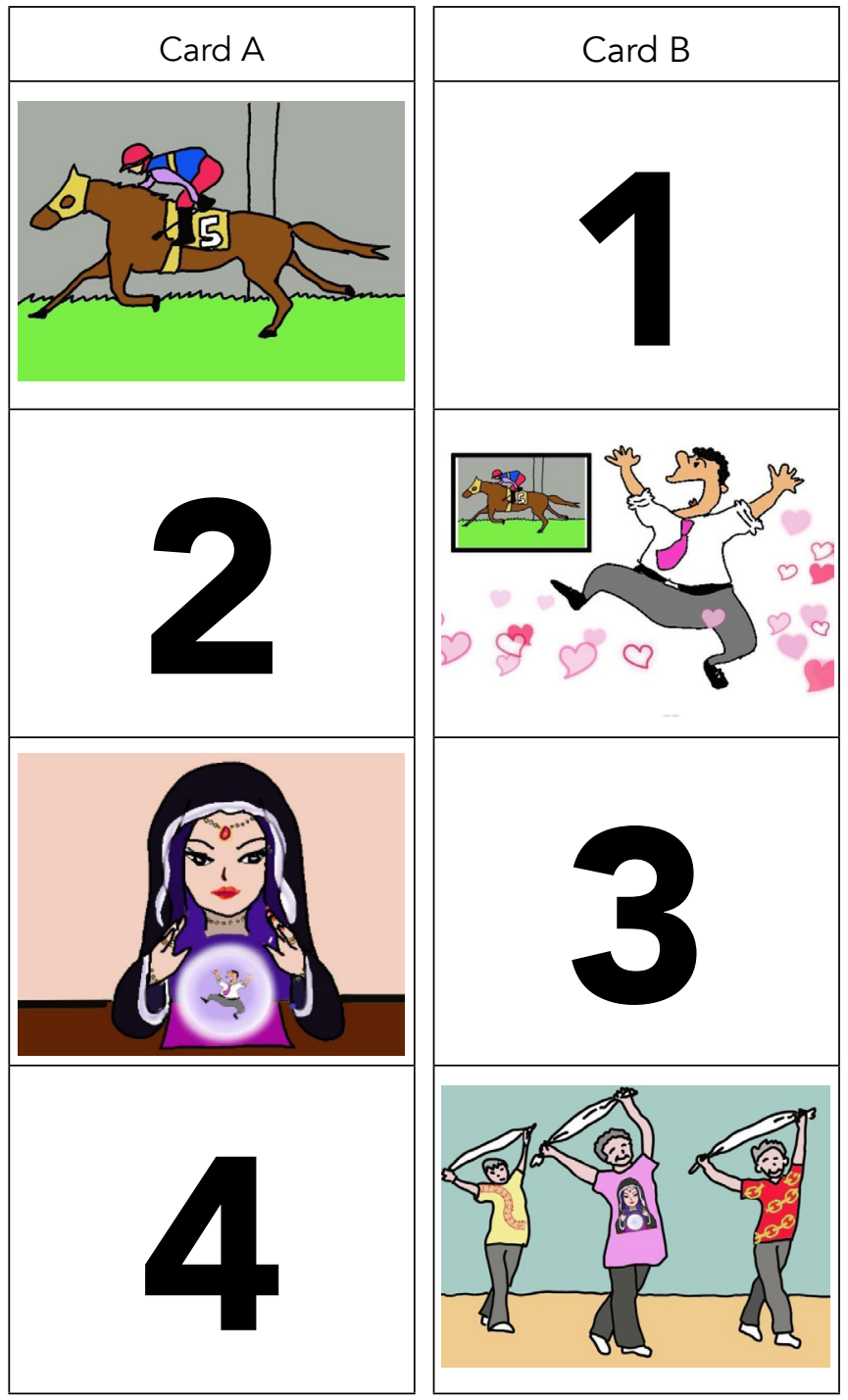

\section{Appendix C}

Example of Picture Cards for Half-Picture Info Gap

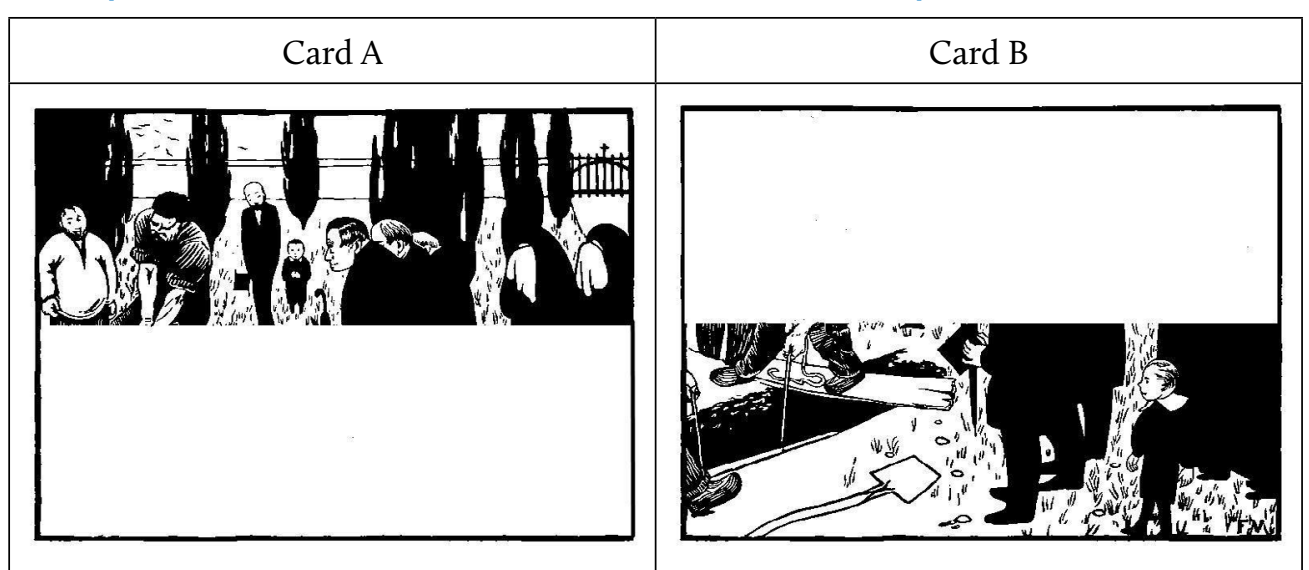

Note: The original image can be found at https://www.oldbookillustrations.com/illustrations/ funeral/

Appendix D

Example of a Picture Card for Back-to-Back Drawing

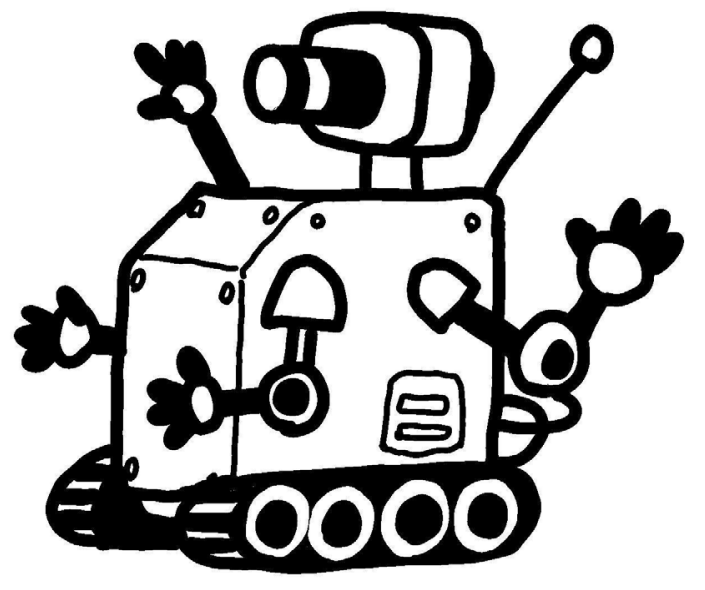




\section{Appendix E}

\section{Communication Skills Questionnaire}

\section{Communication Skills Questionnaire}

$\star$ Answer the following questions either in English or Japanese. Your answers won't affect your grades. Feel free to write whatever you think.

回答は英語でも日本語でもかまいません。成績にはは全く影䇱しませんので、思ったことを自由に書いてください。

How often do you use Checking Understanding as a speaker? 間き手が理解しているかどうかよく碓かめ ますか?

\begin{tabular}{|c|c|c|}
\hline 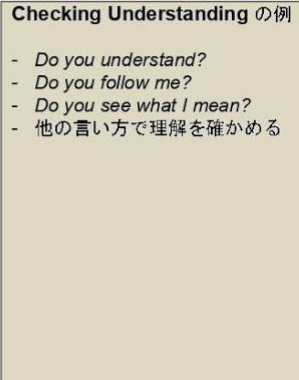 & 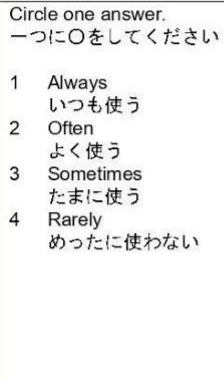 & 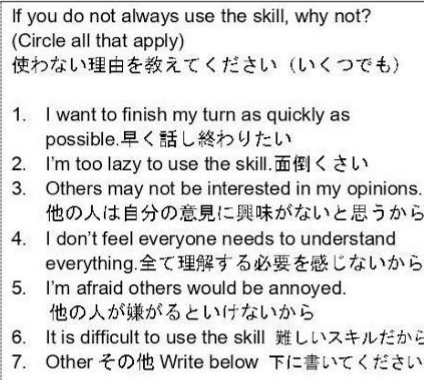 \\
\hline
\end{tabular}

2. When you have difficulty understanding each other during the discussions, do you use the following skills? ディスカッションで、お互いの言っていることがよくわからない時、以下のスキルを使いますか? (1) Saying that you don't understand. 言っていることがよくかからないと言う

\begin{tabular}{|c|c|c|}
\hline 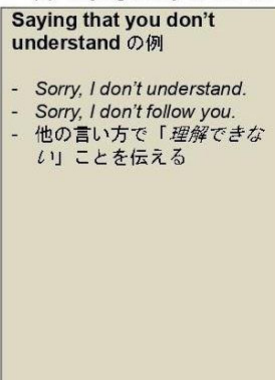 & 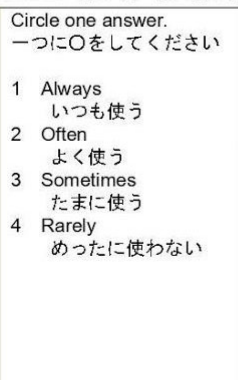 & 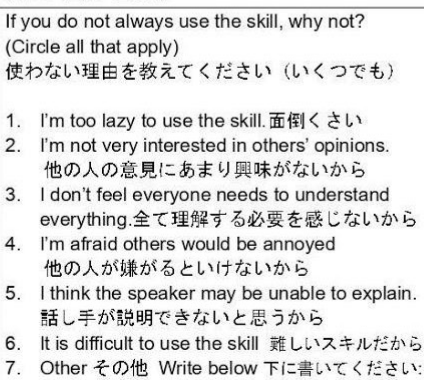 \\
\hline
\end{tabular}

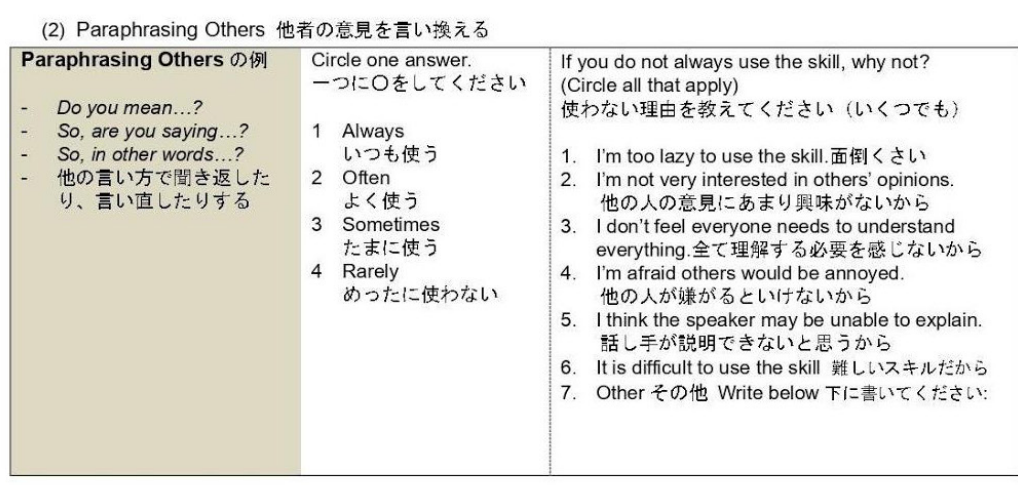

(3) Paraphrasing Yourself 自分の意見を言い换える

Paraphrasing Yourself $\Phi$ 例 Circle one answ

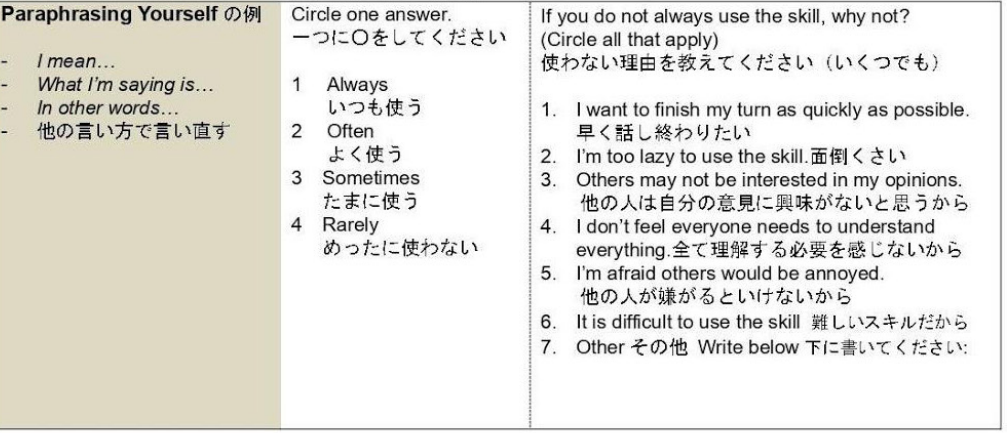

(4) Clarification 碓かめる

\begin{tabular}{|c|c|c|}
\hline 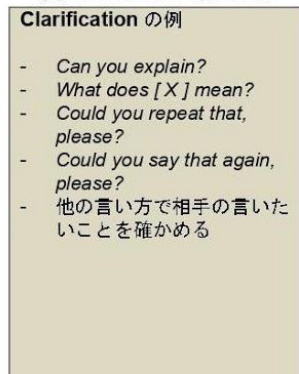 & 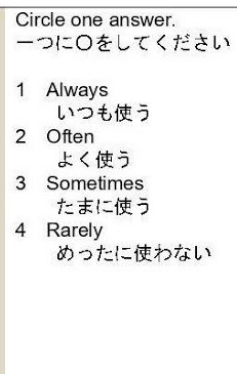 & 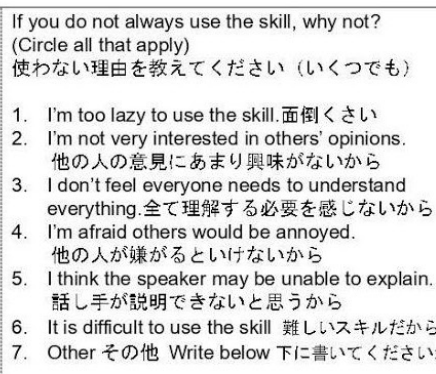 \\
\hline
\end{tabular}

